\title{
Mycobacterium hassiacum sp. nov., a New Rapidly Growing Thermophilic Mycobacterium
}

\author{
K.-H. SCHRÖDER, ${ }^{1}$ L. NAUMANN, ${ }^{2}$ R. M. KROPPENSTEDT, ${ }^{3}$ AND U. REISCHL ${ }^{2 *}$ \\ Labor Dr. Hess und Kollegen, D-34117 Kassel, ${ }^{1}$ Institut für Medizinische Mikrobiologie und Hygiene, \\ Universitätsklinik Regensburg, D-93053 Regensburg, ${ }^{2}$ and Deutsche Sammlung von \\ Mikroorganismen und Zellkulturen GmbH, D-38124 Braunschweig, ${ }^{3}$ Germany
}

\begin{abstract}
A new rapidly growing, scotochromogenic mycobacterium was isolated from urine. This strain is thermophilic (it grows at $65^{\circ} \mathrm{C}$ ), tolerates $5 \% \mathrm{NaCl}$, and was unable to utilize any of the sugars tested or citrate or to take up iron. The isolate splits benzamide, urea, nicotinamide, and pyrazinamide and is sensitive to streptomycin, ethambutol, cycloserine, ciprofloxacin, and chlarithromycin but resistant to isoniazid, rifampin, and prothionamide. These characteristics clearly place this organism in a new mycobacterial species, which was confirmed by the unique 16S rRNA nucleotide sequence. The high level of similarity between this rapid grower and Mycobacterium xenopi is surprising. For this new rapidly growing scotochromogenic and thermophilic mycobacterium we propose the name Mycobacterium hassiacum sp. nov.
\end{abstract}

For decades the term mycobacteria was like a synonym of Mycobacterium tuberculosis; this was true until other mycobacteria (atypical mycobacteria or mycobacteria other than tuberculosis) were detected. The clinical significance of the latter organisms is difficult to estimate because some of them are able to infect humans, but others seem to be never related to disease. Atypical mycobacteria are present in the human environment (32), and therefore it is possible to isolate them from clinical specimens (6). This is why the isolation of atypical mycobacteria represents a clinical and taxonomic problem. The clinical significance is easy to determine (3). More difficult is the problem of identification because the number of new mycobacterial species is always increasing and some of these organisms may behave more or less alike when conventional methods are used. In such cases $16 \mathrm{~S}$ rRNA analysis provides definite identification (27). However, strain $3849^{\mathrm{T}}(\mathrm{T}=$ type strain) can be identified by standard methods, and an analysis of the $16 \mathrm{~S}$ rRNA gene confirms the results.

\section{MATERIALS AND METHODS}

Mycobacterial strain, cellular features, growth temperatures, and biochemica tests. Strain $3849^{\mathrm{T}}$ was isolated $(4,5)$ from urine only once. Growth was observed on Löwenstein-Jensen ( $\mathrm{LJ}$ ) medium and on $12 \mathrm{~B}$ medium.

Besides microscopic and morphological investigations, the following characteristics were studied: pigmentation, growth at $25,31,37,40,45,50,55,60,65$, and $70^{\circ} \mathrm{C}$, growth in the presence of $5 \% \mathrm{NaCl}$, and utilization of sugars and citrate $(6,9,13,24,26)$. The biochemical properties examined are shown in Tables 1 and 2. Tests for drug susceptibility were performed on LJ medium and were interpreted by the modified proportion method $(4,5)$. The properties of strain $3849^{\mathrm{T}}$ and other rapid growers are compared in Tables 1 and 2 .

Culture conditions for fatty acid analyses. Strain $3849^{\mathrm{T}}$ was cultivated on Middlebrook $7 \mathrm{H} 10$ agar (DSM medium $645[3 \mathrm{a}]$ ) at $37^{\circ} \mathrm{C}$ for 1 week. To obtain sufficient cell material for analyses of the other chemical markers, the strain was grown in GPHF liquid medium (DSM medium 553).

Analyses of cell wall amino acids and sugars. Amino acid and sugar analyses of whole-cell hydrolysates were performed by previously described procedures (29).

Extraction and analysis of isoprenoid quinones. Isoprenoid quinones were extracted and purified by the small-scale integrated procedure of Minnikin et al. (19). The isolated and dried menaquinone preparation was dissolved in $200 \mu \mathrm{l}$ of isopropanol. Portions ( 1 to $10 \mu \mathrm{l}$ ) were separated by high-performance liquid

\footnotetext{
* Corresponding author. Mailing address: Institut für Medizinische Mikrobiologie und Hygiene, Universitätsklinik Regensburg, Franz-Josef-Strauß-Allee 11, 93053 Regensburg, Germany. Phone: 49-941-9446451. Fax: 49-941-944-6402. E-mail: Udo.Reischl@klinik.uni-regensburg de.
}

chromatography without further purification by using an RP-18 column ( 250 by $4 \mathrm{~mm}$ ) filled with Lichrospher 100 (particle size, $5 \mathrm{~mm}$ ). The column was kept at $40^{\circ} \mathrm{C}$. Acetonitrile-isopropanol $(65: 35, \mathrm{vol} / \mathrm{vol})$ was used as the mobile phase. The flow rate was $1 \mathrm{ml} / \mathrm{min}(13,14)$.

Extraction and analysis of fatty acids. Fatty acid methyl esters were obtained from $40 \mathrm{mg}$ (wet weight) of cells by saponification, methylation, and extraction by using minor modifications (16) of the method of Miller (18). The fatty acid methyl ester mixtures were separated with a model 5898A microbial identification system (Microbial ID, Newark, Del.), which consisted of a model 5980 gas chromatograph (Hewlett-Packard Co., Palo Alto, Calif.) fitted with a 5\% phenylmethyl silicone capillary column $(0.2 \mathrm{~mm}$ by $25 \mathrm{~m}$ ), a flame ionization detector, a Hewlett-Packard model 3392 integrator, and a Hewlett-Packard model $7673 \mathrm{~A}$ automatic sampler. Peaks were automatically integrated and fatty acid names and percentages were calculated by the Microbial Identification System standard software (Microbial ID). The gas chromatographic parameters were as follows: the carrier gas was ultrahigh-purity hydrogen; the column head pressure was $60 \mathrm{kPa}$; the injection volume was $2 \mu \mathrm{l}$; the column split ratio was $100: 1$; the septum purge rate was $5 \mathrm{ml} / \mathrm{min}$; the column temperature was increased from 170 to $270^{\circ} \mathrm{C}$ at a rate of $5^{\circ} \mathrm{C} / \mathrm{min}$; the injection port temperature was $250^{\circ} \mathrm{C}$; and the detector temperature was $300^{\circ} \mathrm{C}$.

Extraction and analysis of mycolic acids. Freeze-dried bacteria $(50 \mathrm{mg})$ were degraded by treatment at $75^{\circ} \mathrm{C}$ with $3 \mathrm{ml}$ of a methanol-toluene-sulfuric acid mixture $(30: 15: 1, \mathrm{vol} / \mathrm{vol} / \mathrm{vol})$ for $16 \mathrm{~h}(20)$. Long-chain components were extracted with hexane, and traces of acid were removed by passage through a short column of ammonium hydrogen carbonate. The hexane extracts were examined by thin-layer chromatography, using plates $(20$ by $20 \mathrm{~cm})$ coated with silica $(\mathrm{H}$ Merck GmbH, Darmstadt, Germany) (0.5-mm layers) and a developing mixture containing petroleum ether (bp, 60 to $\left.80^{\circ} \mathrm{C}\right)$ and diethyl ether $(85: 15$, vol/vol).

For two-dimensional chromatography 10 - by $10-\mathrm{cm}$ plates with $0.5-\mathrm{mm}$ silica layers (Merck) were used. The plates were developed three times with a mixture containing petroleum ether and acetone $(95: 5, \mathrm{vol} / \mathrm{vol})$ in the first direction and then once with toluene-acetone $(97: 3, \mathrm{vol} / \mathrm{vol})$ in the second direction.

Determination of the DNA $\mathbf{G}+\mathbf{C}$ content. DNA was isolated by using previously described procedures (31). Approximately $20 \mathrm{mg}$ of DNA was hydrolyzed and dephosphorlylated as described previously (17). Nucleosides were separated by reverse-phase high-performance liquid chromatography. The apparatus used consisted of an LKB model 2150 high-pressure pump equipped with an LKB model 2151 UV detector $(270 \mathrm{~nm})$ connected to a Shimadzu model CR-3A integrator. The analytical column was a NUCLEOSIL $100-5 \mathrm{C} 18$ column ( 240 by $4 \mathrm{~mm}$ ) equipped with a NUCLEOSIL $100-5 \mathrm{C} 18$ precolumn ( 20 by $4 \mathrm{~mm}$ ); the solvent system of Tamaoka and Komagata (30) was used. The retention times of the nucleosides were determined with synthetic compounds. Nonmethylated lambda phage DNA with a $\mathrm{G}+\mathrm{C}$ content of $49.858 \mathrm{~mol} \%$ (25) was used as a calibration reference. The $\mathrm{G}+\mathrm{C}$ contents were calculated automatically with a Shimadzu integrator.

PCR-based amplification of 16S rDNA. A single colony of the mycobacterial strain was collected from LJ medium, and chromosomal DNA was extracted as described previously (22). A $1-\mu \mathrm{g}$ portion of bacterial DNA was subjected to PCR with each of the following primer pairs: primers M285 and M264 (12) to obtain a 1,030 -bp amplification product of the $16 \mathrm{~S}$ ribosomal DNA (rDNA) $5^{\prime}$ end; and new primer R247 (GTAGTCCACGCCGTAAACGG) and primer M261 (12) to obtain an approximately 760-bp amplification product of the $16 \mathrm{~S}$ rDNA $3^{\prime}$ end. Broad-range eubacterial primers M285 and M261 were combined with genus-specific primers M264 and R247 to produce a 246-bp overlap between the two amplicons. Standard amplification mixtures were incubated at $95^{\circ} \mathrm{C}$ for 
TABLE 1. Selected criteria for the differentiation of rapidly growing, pigmented mycobacteria

\begin{tabular}{|c|c|c|c|c|c|c|c|c|c|c|c|c|c|c|c|c|c|c|}
\hline \multirow[b]{2}{*}{ Species } & \multirow[b]{2}{*}{$\begin{array}{l}\text { Pigmen- } \\
\text { tation }^{a}\end{array}$} & \multicolumn{5}{|c|}{ Growth at: } & \multirow{2}{*}{$\begin{array}{c}\text { Tolerance } \\
\text { to } 5 \% \\
\mathrm{NaCl}\end{array}$} & \multicolumn{5}{|c|}{ Acid production from: } & \multicolumn{2}{|c|}{ Utilization of: } & \multirow[b]{2}{*}{ Niacin } & \multirow{2}{*}{$\begin{array}{l}\text { Nitrate } \\
\text { reduc- } \\
\text { tion }\end{array}$} & \multirow{2}{*}{$\begin{array}{l}\text { Semi- } \\
\text { quanti- } \\
\text { tative } \\
\text { catalase } \\
\text { activity }\end{array}$} & \multirow{2}{*}{$\begin{array}{l}\text { Catalas } \\
\text { activity } \\
\left(68^{\circ} \mathrm{C}\right)\end{array}$} \\
\hline & & $25^{\circ} \mathrm{C}$ & $31^{\circ} \mathrm{C}$ & $37^{\circ} \mathrm{C}$ & $40^{\circ} \mathrm{C}$ & $45^{\circ} \mathrm{C}$ & & $\begin{array}{l}\text { Ino- } \\
\text { sitol }\end{array}$ & $\begin{array}{l}\text { Man- } \\
\text { nitol }\end{array}$ & $\begin{array}{l}\text { Glu- } \\
\text { cose }\end{array}$ & $\begin{array}{l}\text { Su- } \\
\text { crose }\end{array}$ & $\begin{array}{l}\text { Arab- } \\
\text { inose }\end{array}$ & $\begin{array}{l}\text { Iron } \\
\text { (iron up- } \\
\text { take) }\end{array}$ & $\begin{array}{l}\text { Sodium } \\
\text { citrate }\end{array}$ & & & & \\
\hline M. hassiacum & $\mathrm{S}$ & $-^{b}$ & + & + & + & $+^{c}$ & + & - & - & - & - & & - & - & - & - & + & + \\
\hline M. aunum & $\mathrm{S}$ & + & + & + & - & - & \pm & + & + & + & \pm & + & + & + & - & $\mathrm{V}$ & + & \pm \\
\hline M. diernhoferi & NP & + & + & + & + & - & - & + & + & & - & & + & - & - & \pm & & - \\
\hline M. duvalii & $\mathrm{S}$ & & & + & + & - & & - & + & + & - & - & - & - & & + & & \\
\hline M. flavescens & $\mathrm{S}$ & + & + & + & + & - & + & - & V & + & - & - & - & - & - & + & + & + \\
\hline M. gadium & $\mathrm{S}$ & & & + & - & - & & + & - & + & - & - & - & - & & + & & \\
\hline M. gilvum & S & & & + & - & - & & + & + & + & - & - & + & + & & + & & \\
\hline M. komossense & $\mathrm{S}$ & & & & & & - & & & & & - & + & & & - & & \\
\hline M. marinum & $\mathrm{P}$ & + & + & - & - & - & - & - & - & \pm & - & & - & - & - & - & - & + \\
\hline$M$. neoaurum & $\mathrm{S}$ & & & + & & - & + & + & + & + & - & + & + & + & & \pm & & \\
\hline M. parafortuitum & SP & & & + & + & - & + & \pm & + & + & \pm & + & \pm & + & & $\mathrm{V}$ & & \\
\hline M. phlei & $\mathrm{S}$ & + & + & + & + & + & + & - & + & + & - & + & + & + & - & + & + & + \\
\hline M. senegalense & $\mathrm{S}$ & & & & & & + & & + & & & & - & + & & + & & \\
\hline M. sphagni & $\mathrm{S}$ & & & & & & - & & & & & - & - & & & + & & \\
\hline M. thermoresistibile & $S$ & + & + & + & + & $+{ }^{d}$ & \pm & - & $\mathrm{V}$ & - & - & - & - & - & - & + & & \\
\hline$M$. vaccae & SP & + & + & + & + & - & $\mathrm{V}$ & + & + & + & + & \pm & + & + & - & + & + & + \\
\hline
\end{tabular}

"S, scotochromogenic; $\mathrm{P}$, photochromogenic; $\mathrm{N}$, nonphotochromogenic.

$b-$ less than $15 \%$ of the isolates are positive; + , more than $85 \%$ of the isolates are positive; $\mathrm{V}, 16$ to $85 \%$ of the isolates are positive; \pm , weak reaction may occur.

" $M$. hassiacum grows at $65^{\circ} \mathrm{C}$.

${ }^{d}$ M. thermoresistibile grows at $52^{\circ} \mathrm{C}$.

$2 \mathrm{~min}$, at $68^{\circ} \mathrm{C}$ for $1 \mathrm{~min}$, at $95^{\circ} \mathrm{C}$ for $1 \mathrm{~min}$, at $68^{\circ} \mathrm{C}$ for $1 \mathrm{~min}$, and at $95^{\circ} \mathrm{C}$ for 1 min. Immediately afterward 35 cycles of the following temperature profile were applied: $95^{\circ} \mathrm{C}$ for $40 \mathrm{~s}, 55^{\circ} \mathrm{C}$ for $40 \mathrm{~s}$, and $72^{\circ} \mathrm{C}$ for $1.5 \mathrm{~min}$. The PCR mixtures were extracted with phenol and subjected to agarose gel electrophoresis. Extraction and purification of the amplicons were performed with a QuiaEx-II purification kit (Qiagen GmbH, Hilden, Germany).

DNA sequencing. Cycle sequencing reactions for the $16 \mathrm{~S}$ rDNA amplicons were carried out as described in the PRISM Ready Reaction DyeDeoxy terminator cycle sequencing kit protocol (1). Optimal results were obtained with the following forward and reverse sequencing primers: primer M285 (12) and new primer R928 (CCTTTGAGTTTTAGCCTTGC) for the 1,030-bp amplicon; and new primer R249 (GGATCCGTGCCGTAGCTAACGC) and primer M261 (12) for the 760-bp amplicon. The fluorescence-labelled reaction products were analyzed with a model 373A automated DNA sequencer (Applied Biosystems $\mathrm{GmbH}$, Weiterstadt, Germany). Interpretation of the results was accomplished with the help of the SeqEd 1.03 software package (Applied Biosystems).

Sequence and phylogenetic analysis. Comparison and alignment of the 16S rDNA nucleotide sequences were aided by the Sequence Analysis package, version 8.1 (Genetics Computer Group, Madison, Wis.). Analysis was based on mycobacterial $16 \mathrm{~S}$ rDNA sequences published previously and available from the GenBank and EMBL databases. Calculation of distance matrices and construction of phylogenetic trees were carried out with the help of either the unweighted pair group with mathematical average method or the neighbor-joining algorithm of the Sequence Analysis Package, version 8.1.

Nucleotide sequence accession number. The nucleotide sequence of the noncoding (RNA-like) strand of the 16S rRNA gene of Mycobacterium hassiacum sp. nov. has been deposited in the GenBank database under accession number U49401.

\section{RESULTS}

Microscopy and culture. Strain $3849^{\mathrm{T}}$ showed partial acid fastness like other rapid growers $(7,21)$. After growth at 60 to

TABLE 2. Selected criteria for the differentiation of rapidly growing, pigmented mycobacteria ${ }^{a}$

\begin{tabular}{|c|c|c|c|c|c|c|c|c|c|c|}
\hline \multirow{2}{*}{ Species } & \multirow{2}{*}{$\begin{array}{c}\text { Tween } \\
\text { hydrolysis }\end{array}$} & \multirow{2}{*}{$\begin{array}{l}\text { Arylsulfatase } \\
\text { (3 days) }\end{array}$} & \multirow{2}{*}{$\begin{array}{c}\text { Acid } \\
\text { phosphatase }\end{array}$} & \multicolumn{7}{|c|}{ Amides } \\
\hline & & & & Acetamide & Benzamide & Urea & Nicotinamide & Pyracinamide & Succinamide & Allantoin \\
\hline M. hassiacum & $-{ }^{b}$ & - & \pm & - & + & + & + & + & - & - \\
\hline M. aurum & + & $\mathrm{V}$ & - & & - & + & & & - & - \\
\hline M. diemhoferi & & - & - & + & - & & + & + & - & - \\
\hline M. duvalii & + & - & - & & & & & & & \\
\hline M. flavescens & + & $\mathrm{V}$ & \pm & - & - & + & + & + & - & - \\
\hline M. gadium & - & - & + & & - & & & & - & - \\
\hline M. gilvum & + & + & & & & & & & & \\
\hline M. komossense & & - & & & - & & & & + & - \\
\hline M. marinum & + & - & + & & & + & + & \pm & & \\
\hline$M$. neoaurum & + & - & - & & - & & & & - & + \\
\hline M. parafortuitum & + & - & - & \pm & + & + & + & + & $(+)$ & + \\
\hline M. phlei & \pm & - & \pm & \pm & - & + & + & + & - & - \\
\hline M. senegalense & & & & + & + & & & & & + \\
\hline M. sphagni & & - & & & - & & & & - & - \\
\hline M. thermoresistibile & + & - & \pm & - & - & + & + & + & - & - \\
\hline M. vaccae & + & $\mathrm{V}$ & - & + & + & + & + & + & \pm & + \\
\hline
\end{tabular}

${ }^{a}$ Data from references $8,11,15,24$, and 26 . Blank spaces indicate that the information is not currently available or that the property is unimportant.

${ }^{b}-$, usually present in less than $15 \%$ of the isolates; + , usually present in more than $85 \%$ of the isolates; $(+)$, usually present in 16 to $85 \%$ of the isolates; $\mathrm{V}$, positive reaction observed in 16 to $85 \%$ of the isolates; \pm , usually absent or a weak reaction is possible. 
TABLE 3. Fatty acids of $M$. hassiacum

\begin{tabular}{|c|c|}
\hline Fatty acid & $\%$ \\
\hline \multicolumn{2}{|l|}{$14: 0 \ldots$} \\
\hline \multicolumn{2}{|l|}{$15: 0 \ldots}$. \\
\hline \multicolumn{2}{|l|}{$16: 1$ cis $9 \ldots$} \\
\hline \multicolumn{2}{|c|}{$16: 1$ cis $10 \ldots \ldots$} \\
\hline \multicolumn{2}{|c|}{$16: 0$} \\
\hline \multicolumn{2}{|c|}{ 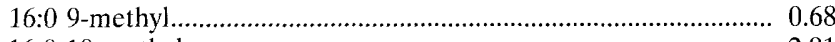 } \\
\hline \multicolumn{2}{|c|}{ 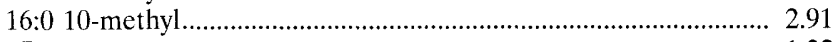 } \\
\hline \multicolumn{2}{|c|}{$17: 0$} \\
\hline \multicolumn{2}{|l|}{$18: 1 \mathrm{c}$} \\
\hline \multicolumn{2}{|c|}{ 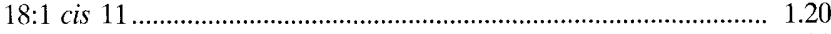 } \\
\hline \multicolumn{2}{|c|}{ 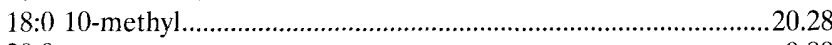 } \\
\hline \multicolumn{2}{|c|}{$20: 0$} \\
\hline \multirow{2}{*}{\multicolumn{2}{|c|}{$18: 0$ alcohol }} \\
\hline & \\
\hline
\end{tabular}

$65^{\circ} \mathrm{C}$ the rods were longer and thinner than after growth at $37^{\circ} \mathrm{C}$.

The strain was scotochromogenic and grew within 2 to 3 days after inoculation. The morphology of the colonies was depen- dent on the incubation temperature. At $37^{\circ} \mathrm{C}$ the colonies were about 2 to $5 \mathrm{~mm}$ in diameter and moist but slimy in dense growth. After growth at about $60^{\circ} \mathrm{C}$ the colonies were distinct but more or less dry. Strain $3849^{\mathrm{T}}$ also grew at $65^{\circ} \mathrm{C}$, which was remarkable. Higher temperatures seemed to favor growth.

The isolate tolerated $5 \% \mathrm{NaCl}$ and was unable to utilize any of the sugars tested or citrate or to take up iron. Enzymatic activity was low; no accumulation of niacin, no reduction of nitrate, no hydrolysis of Tween 80 , and no arylsulfatase activity were observed. In contrast, catalase was detected and was not inactivated by heating at $68^{\circ} \mathrm{C}$. The strain possessed benzamidase, urease, nicotinamidase, and pyrazinamidase. The acid phosphatase activity was weak. The strain was susceptible to streptomycin (4 mg/liter), ethambutol ( $1 \mathrm{mg} /$ liter), cycloserine (16 mg/liter), ciprofloxacin $(0.5 \mathrm{mg} /$ liter $)$, and clarithromycin ( $0.5 \mathrm{mg} /$ liter) but resistant to isoniazid (1 mg/liter), rifampin (32 $\mathrm{mg} /$ liter), and prothionamide $(32 \mathrm{mg} / \mathrm{liter})$.

Chemotaxonomic analyses. The cell walls of strain $3849^{\mathrm{T}}$ contained arabinose and galactose as major cell wall sugars, and meso-diaminopimelic acid was the only diamino acid. MK$9\left(\mathrm{H}_{2}\right)$ was the predominant menaquinone, and small amounts
CGAACGCTGGCGGCGTGCTTAACACATGCAAGTCGAACGGAAAGGCCCCTTCGGGGGTAC . GGGAAACTGGGTCTAATACCGGATATTCCTTCTGGCCGCATGGTTGGTTGGGGAAAGC TTATGTAGCGGTGTGGGA GGCCCGCGGCCTATCAGCTTGTTGGTGGGGTGATGGCCTA CCAAGGCGACGACGGGTAGCCGGCCTGAGÄGGTGACCGGCCACACTGGGACTGAGATAC GGCCCAGACTCCTACGGGAGGCAGCAGTGGGGAATATTGCACAATGGGCGCAAGCCTGAT GCAGCGACGCCGCGTGAGGGATGACGGCCTTCGGGTTGTAAACCTCTTTCAGCGCCGACG AAGCGTAAGTGACGGTAGGCGCAGAAGAÁंCACCGGCCAAंCTACGTGCCÄGCAGCCGCGG TAATACGTAGGGTGCGAGCGTTGTCCGGAAंTTACTGGGCGTAAAGAGCTCGTAGGTGGTT TGTCGCGTTGTCCGTGAAATCCCACGGCTTAACTGTGGGCGTGCGGGCGÁTACGGGCAGA CTAGAGTGCTGCAGGGGAGACTGGAATTCCTGGTGTAGCGGTGGAATGCGCAGATATCA GAGGAACACCGGTGGCGAAGGCGGGTCTCTंGGGCAGCTACंTGACGCTGAGGAGCGAAAGC GTGGGGAGCGAACAGGATTAGATACCCTGGTAGTCCACGCCGTAAACGGTGGGTACTAGG TGTGGGTTCTTTCCTAAGGAंTCCGTGCCGTAGCTAACGCAंTAAAGTACCCCGCCTGGGGA் GTACGGCCGCAAGGCTAAAACTCAAAGGAATTGACGGGGGCCCGCACAAGCGGCGGAGCA TGTGGATTAÄTCGATGCAACGCGAAGAACCTTACCTGGGTTTGACATGCACAGGACGCG TCTAGAGATAGGCGTTCCCTTTGGGCCTGTGTGCAGGTGGTGCATGGCTGTCGTCAGCTC GTGTCGTGAGATGTTGGGTTAAGTCCCGCAACGAGCGCAACCCTTGTCCCATGTTGCCAG CGGGTGATGCCGGGGACTCÁTGGGAGACTGCCGGGGTCAACTCGGAGGAÄGGTGGGGATG ACGTCAAGTCATCATGCCCCTTATGTCCAGGGCTTCACACATGCTACAATGGCCGGTACA AAGGGCTGCGAAGCCGTGAGGTGGAGCGAÄTCCCTGCAAÄGCCGGTCTCÁGTTCGGATCG GGGTCTGCAACTCGACCCCGTGAAGTCGGÄGTCGCTAGTAAATCGCAGATCAGCAACGCTG CGGTGAATACGTTCCCGGGCCTTGTACACACCGCCCGTCACGTCATGAAÁGTCGGTAACA CCCGAAGCCGGTGGCCTAACCCGTCAGGGAGGGAGCCGTC̈GAAGGTGGGAंTCGGCGATTG

60 120 180 240 300 360 420 480 540 600 660 720 780 840 900 960 GGACGAAGTCGTAACAAGGTAGCCGTACCGGAAGGTGCGGATGGATCACCT

FIG. 1. Nucleotide sequence of the noncoding (RNA-like) strand of the 16S rRNA gene from the novel species $M$. hassiacum. The corresponding positions of the E. coli $16 \mathrm{~S}$ rRNA gene are shown in parentheses for reference. 
TABLE 4. 16S rRNA similarity matrix ${ }^{a}$

\begin{tabular}{|c|c|c|c|c|c|c|c|c|c|c|c|c|c|c|c|c|c|c|c|c|c|c|}
\hline \multirow[b]{2}{*}{ Taxon } & \multicolumn{22}{|c|}{$\%$ Similarity to: } \\
\hline & 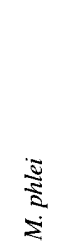 & 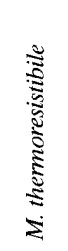 & 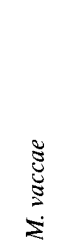 & 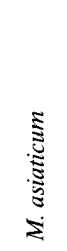 & 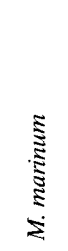 & 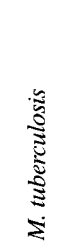 & 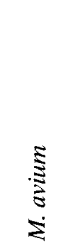 & 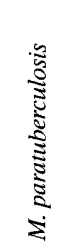 & 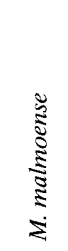 & 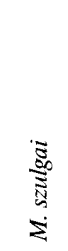 & 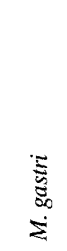 & 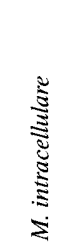 & 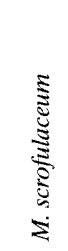 & 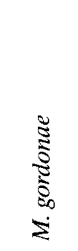 & 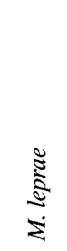 & 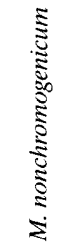 & 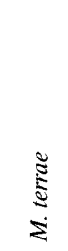 & 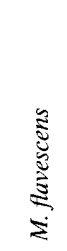 & $\frac{\tilde{E}}{\stackrel{5}{E}}$ & 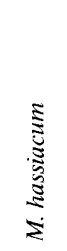 & 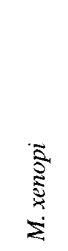 & 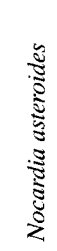 \\
\hline M. komossense & 96.7 & 95.9 & 96.6 & 96.1 & 96.3 & 96.0 & 95.4 & 95.6 & 95.6 & 95.8 & 95.4 & 95.6 & 95.8 & 95.3 & 95.0 & 96.5 & 97.0 & 97.6 & 97.8 & 97.3 & 94.3 & 93.7 \\
\hline M. phlei & & 96.8 & 96.8 & 96.4 & 95.3 & 95.1 & 94.6 & 94.7 & 94.8 & 95.0 & 95.0 & 94.9 & 95.0 & 95.1 & 94.3 & 96.3 & 97.3 & 98.5 & 96.7 & 94.8 & 94.1 & 92.4 \\
\hline M. thermoresistibile & & & 96.5 & 96.0 & 94.3 & 94.2 & 94.0 & 94.1 & 94.4 & 94.5 & 94.3 & 94.6 & 94.6 & 94.8 & 93.0 & 95.7 & 96.1 & 97.6 & 96.5 & 96.2 & 93.1 & 92.1 \\
\hline M. vaccae & & & & 95.7 & 94.8 & 94.7 & 94.7 & 94.8 & 95.0 & 95.1 & 94.8 & 94.9 & 94.8 & 94.7 & 93.9 & 95.2 & 95.4 & 97.7 & 97.2 & 94.8 & 92.8 & 93.0 \\
\hline M. asiaticum & & & & & 97.4 & 97.0 & 97.3 & 97.4 & 97.7 & 97.8 & 97.4 & 97.5 & 97.0 & 97.8 & 96.3 & 96.2 & 96.8 & 96.4 & 96.0 & 94.6 & 94.2 & 92.6 \\
\hline M. marinum & & & & & 99.2 & 98.6 & 98.6 & 98.5 & 98.7 & 98.5 & 98.4 & 98.3 & 97.9 & 98.0 & 96.1 & 96.6 & 95.0 & 96.0 & 94.6 & 95.6 & 92.8 & \\
\hline M. tuberculosis & & & & & & 98.5 & 98.5 & 98.7 & 98.8 & 98.8 & 98.4 & 98.2 & 97.7 & 98.2 & 95.9 & 96.6 & 95.1 & 95.7 & 94.7 & 95.7 & 92.9 & \\
\hline M. avium & & & & & & & 99.9 & 98.9 & 99.0 & 98.8 & 99.4 & 98.6 & 98.0 & 98.1 & 95.9 & 96.1 & 94.5 & 95.4 & 94.7 & 95.0 & 92.7 & \\
\hline M. paratuberculosis & & & & & & & & 99.0 & 99.1 & 98.9 & 99.5 & 98.7 & 98.0 & 98.2 & 96.0 & 96.2 & 94.6 & 95.5 & 94.7 & 95.1 & 92.9 & \\
\hline M. malmoense & & & & & & & & & 99.8 & 99.1 & 99.1 & 98.7 & 98.1 & 98.3 & 95.7 & 95.9 & 95.0 & 95.6 & 95.0 & 95.3 & 92.7 & \\
\hline M. szulgai & & & & & & & & & & 99.2 & 99.2 & 98.8 & 98.2 & 98.2 & 95.2 & 96.1 & 95.0 & 95.7 & 95.1 & 95.4 & 92.9 & \\
\hline M. gastri & & & & & & & & & & & 98.9 & 98.9 & 98.0 & 98.0 & 95.4 & 96.0 & 94.6 & 95.4 & 95.0 & 95.1 & 92.6 & \\
\hline M. intracellulare & & & & & & & & & & & & 98.8 & 97.9 & 98.1 & 95.7 & 96.1 & 94.8 & 95.3 & 94.9 & 95.3 & 92.8 & \\
\hline M. scrofulaceum & & & & & & & & & & & & & 97.8 & 97.7 & 95.6 & 96.0 & 94.7 & 95.5 & 95.0 & 95.1 & 92.6 & \\
\hline M. gordonae & & & & & & & & & & & & & & 97.0 & 96.1 & 96.7 & 95.4 & 95.9 & 93.7 & 95.1 & 93.4 & \\
\hline M. leprae & & & & & & & & & & & & & & & 94.9 & 95.2 & 94.9 & 94.5 & 93.8 & 94.8 & 92.3 & \\
\hline M. nonchromogenicum & & & & & & & & & & & & & & & & 98.3 & 96.8 & 97.3 & 94.1 & 94.7 & 92.1 & \\
\hline M. terrae & & & & & & & & & & & & & & & & & 97.1 & 97.1 & 94.6 & 95.0 & 92.6 & \\
\hline M. flavescens & & & & & & & & & & & & & & & & & & 97.5 & 95.3 & 93.8 & 93.3 & \\
\hline M. fortuitum & & & & & & & & & & & & & & & & & & & 94.6 & 94.0 & 94.1 & \\
\hline M. hassiacum & & & & & & & & & & & & & & & & & & & & 94.2 & 91.0 & \\
\hline M. xenopi & & & & & & & & & & & & & & & & & & & & & 91.1 & \\
\hline
\end{tabular}

${ }^{a}$ The values are levels of similarity corrected for multiple base changes by the method of Jukes and Cantor with standard parameters. The accession numbers for sequences obtained from GenBank are as follows: $M$. komossense, X55591; M. phlei, M29566; M. thermoresistibile, X55602; M. vaccae, X55601; M. asiaticum, X55604; M. marinum, X52920; M. tuberculosis, X52917; M. avium, X52918; M. paratuberculosis, X52934; M. malmoense, X52930; M. szulgai, X52926; M. gastri, X52919; M. intracellulare, X52927; M. scrofulaceum, X52924; M. gordonae, X52923; M. leprae, X53999; M. nonchromogenicum, X52928; M. terrae, X52925; M. flavescens, X52932; M. fortuitum, X52921; M. hassiacum, U49401; M. xenopi, M61664; and N. asteroides, X57949.

of MK-8 $\left(\mathrm{H}_{2}\right)$ were also found. An analysis of the fatty acids from whole cells revealed a pattern of straight-chain, saturated and unsaturated fatty acids along with significant amounts of tuberculostearic acid (10-methyl octadecanoic acid). Two alcohols, octadecanol and eicosanol, were also present (Table 3). Strain $3849^{\mathrm{T}}$ could not be identified on the basis of its fatty acid pattern by using the MIDI mycobacterial database. One-dimensional thin-layer chromatography of whole-organism acid methanolysates of strain $3849^{\mathrm{T}}$ indicated that this organism synthesizes mycolic acids that include a-mycolates and wax esters. Two-dimensional thin-layer chromatography resulted in a more precise separation of the components, especially the a-mycolates, the $\alpha^{\prime}$-mycolates, and the keto-mycolates, but only a-mycolates and alcohols could be detected.

$\mathbf{G}+\mathbf{C}$ content. The $\mathrm{G}+\mathrm{C}$ content of strain $3849^{\mathrm{T}}$ was 65.8 $\operatorname{mol} \%$.

16S rRNA sequence analysis. Using the strategy of Kirschner et al. (12) and selecting appropriate PCR and sequencing primers, we determined an almost complete nucleotide sequence of the gene coding for the small 16S rRNA subunit (Fig. 1). When it was compared with 60 mycobacterial $16 \mathrm{~S}$ rRNA sequences, the sequence of strain $3849^{T}$ was found to be unique (data not shown). Detailed examination of the $16 \mathrm{~S}$ rRNA sequence demonstrated complete homology in genusspecific regions, but revealed a number of differences in species-specific regions. In particular, the highly variable region (2) contained a stretch of 24 nucleotides which differed significantly from the nucleotides in other mycobacterial species
(Fig. 1, positions 180 to 210 ). As in some other thermotolerant mycobacteria, a one-nucleotide insertion was observed at position 186 of the $16 \mathrm{~S}$ rRNA gene within helix 10 (28). An additional two-nucleotide insertion at position 221 (Escherichia coli 16S rRNA gene position) appeared to be unique for strain $3849^{\mathrm{T}}$. In contrast to the majority of the slowly growing mycobacteria but like several fast-growing mycobacteria, a short helix 18 was observed (28).

Phylogenetic analysis. In addition to allowing rapid and unambiguous species identification, the availability of the $16 \mathrm{~S}$ rRNA sequence allows phylogenetic relationships to be studied (12, 23). A phylogenetic tree inferred from the results of the sequence similarity analyses (Table 4) is shown in Fig. 2. Elements of this tree have been reported in previous phylogenetic studies (23). Comparisons with every mycobacterial $16 \mathrm{~S}$ rRNA sequence available revealed that the highest degree of phylogenetic relatedness was the degree of relatedness with Mycobacterium xenopi (Fig. 2). Although $M$. hassiacum is a rapidly growing mycobacterium, its $16 \mathrm{~S}$ rRNA sequence places it in a phylogenetic subgroup whose only member is the slowly growing organism $M$. xenopi (level of similarity, 94.20\%).

\section{DISCUSSION}

If acid-fast bacteria are detected in human specimens and are atypical mycobacteria, it is important to decide whether there is an infection or colonization. For this decision identification of the isolate is necessary. Strain $3849^{\mathrm{T}}$ was isolated 


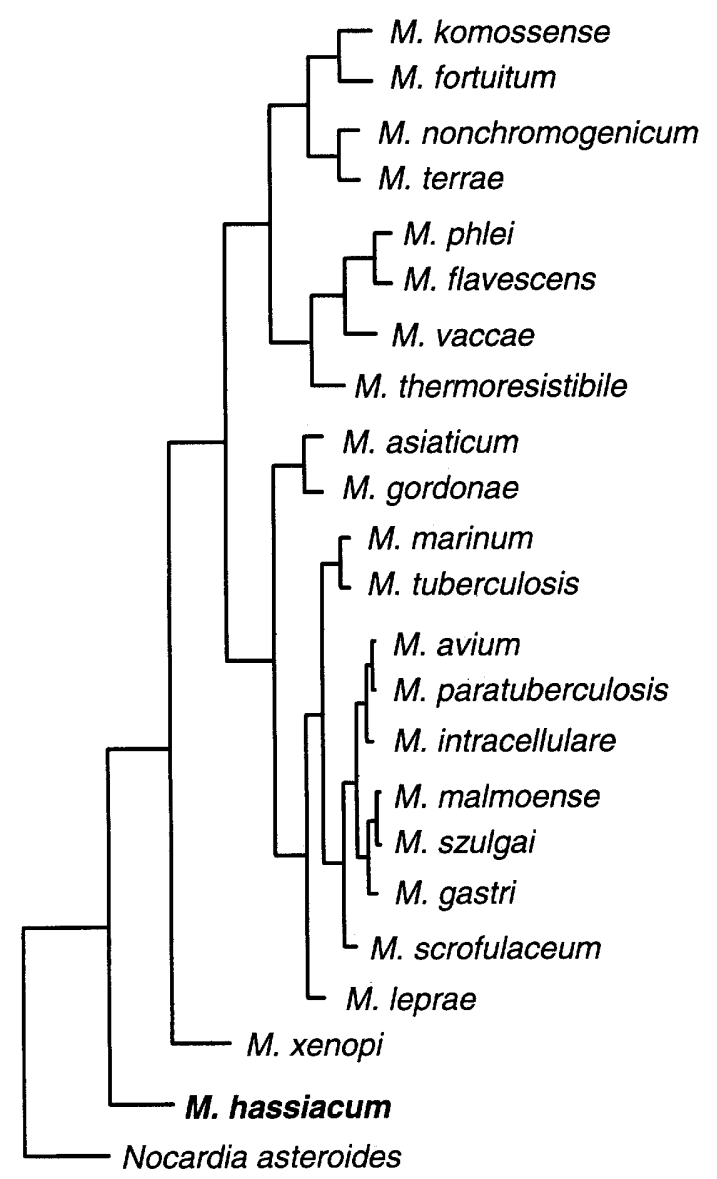

FIG. 2. Phylogenetic tree for selected members of the genus Mycobacterium Nocardia asteroides was used as the outgroup. The tree was inferred from the data in Table 4 based on the unweighted pair group with mathematical average algorithm of the Sequence Analysis software package (version 8.1), using standard parameters. Bar $=10$ nucleotide differences.

from urine only once and is, at least for our patient, apathogenic. This finding is in agreement with the finding of clinicians, who wanted to exclude an infection of the urogenital tract. It is also consistent with practical information because rapid growers never seem to be related to infections of the urogenital tract. Such infections do occur very rarely after surgical intervention (9).

M. hassiacum is easy to distinguish from other mycobacteria. The most important property for identification is growth at $65^{\circ} \mathrm{C}$. No other mycobacterium seems to be as thermotolerant as $M$. hassiacum. Growth at $53^{\circ} \mathrm{C}$ has been observed only with Mycobacterium phlei and Mycobacterium thermoresistibile (11, $15,24)$, and other mycobacteria grow at $60^{\circ} \mathrm{C}(8)$. In addition, the inability to utilize any sugar is remarkable, and splitting of benzamide has been observed in only three other rapidly growing species (Table 2).

$M$. hassiacum has the typical combination of chemical markers which are diagnostic for all species of the genus Mycobacterium, including meso-diaminopimelic acid and arabinose plus galactose in whole-cell hydrolysates, quinone $\mathrm{MK}-9\left(\mathrm{H}_{2}\right)$, a fatty acid pattern composed of unbranched saturated and unsaturated fatty acids plus tuberculostearic acid, and mycolic acids having a chain length of about 90 carbon atoms. The occurrence of two alcohols, 18:0 and 20:0, in the fatty acid pattern (free of wax esters) placed $M$. hassiacum in a fatty acid cluster which also contains Mycobacterium avium, Mycobacterium intacellulare, Mycobacterium scrofulaceum, Mycobacterium terrae, and $M$. phlei.

Consistent with the results described above, molecular evidence that strain $3849^{\mathrm{T}}$ belongs to a novel species in the genus Mycobacterium comes from the 16S rRNA sequence, which is unique. Within the species-specific $16 \mathrm{~S}$ rDNA region, there are significant differences from other mycobacteria, and these differences may provide a unique target region for DNA probes or nucleic acid-based diagnostic procedures for specific detection of $M$. hassiacum.

Regarding the molecular signature sequences in the $16 \mathrm{~S}$ rRNA gene, a one-nucleotide insertion was observed at position 186 in helix 10 and an additional two-nucleotide insertion was found at position 221 ( $E$. coli $16 \mathrm{~S}$ rRNA gene positions). According to Springer et al. (28), a two-nucleotide insertion in helix 10 allows the isolate to be assigned to a subgroup of rapid growers characterized as thermotolerant. In this study a threenucleotide insertion was observed which corroborates the phylogenetic position of $M$. hassiacum within the group of rapidly growing mycobacteria. Moreover, the short helix 18 in the $16 \mathrm{~S}$ rRNA gene of $M$. hassiacum represents the typical molecular signature of rapidly growing species.

Sequence analysis of the 16S rRNA gene is a very successful method for bacterial identification, and several species have been detected only by this technique. The identities of Mycobacterium genavense and Mycobacterium malmoense, for example, could be misinterpreted without sequence analysis (10). In contrast, other species are easily distinguished by conventional procedures but cannot be differentiated on the 16S rRNA level. For example, Mycobacterium tuberculosis and Mycobacterium bovis, Mycobacterium kansasii and Mycobacterium gastri (23), and M. malmoense and Mycobacterium szulgai show a $16 \mathrm{~S}$ rRNA sequence similarity value of $99.9 \%$ (23).

The phylogenetic position of rapidly growing strain $3849^{\mathrm{T}}$ among the slow growers is unexpected and very similar to the position of $M$. xenopi (Fig. 2). A similar observation has been made with Mycobacterium simiae, which occupies an intermediate position between the slow growers and the rapid growers. This could be explained by the presence of sequence elements typical of slow and rapid growers (23). Although phylogenetic trees give valuable information, it is hard to understand why, for example, $M$. bovis and Mycobacterium marinum show a level of sequence similarity of $99.4 \%$ and behave so differently in conventional tests.

Description of Mycobacterium hassiacum sp. nov. Mycobacterium hassiacum (has.si'a.cum. M. L. adj. hassiacum, referring to the German province of Hesse, where the organism was first isolated). The rod-shaped cells show partial acid-alcohol fastness. Colonies grown on LJ medium are scotochromogenic, 2 to $5 \mathrm{~mm}$ in diameter, smooth, and (in dense growth) slimy. When colonies are grown at 40 to $65^{\circ} \mathrm{C}$, they are distinct and drier. The strain grows at temperatures between 30 and $65^{\circ} \mathrm{C}$, tolerates $5 \% \mathrm{NaCl}$, does not utilize sugars, and is unable to take up iron and citrate. $M$. hassiacum is susceptible to streptomycin, ethambutol, cycloserine, ciprofloxacin, and clarithromycin but resistant to isoniazid, rifampin, and prothionamide. Positive for benzamidase, urease, nicotinamidase, pyrazinamidase, and a heat-stable catalase. The acid phosphatase activity is only weak. Negative for niacin, nitrate reductase, and hydrolysis of Tween 80, as well as acetamidase, succinamidase, and allantoinamidase. The $16 \mathrm{~S}$ rRNA sequence demonstrates that this taxon is a novel species. Although its sequence has molecular signatures of thermotolerant and rapidly growing bacteria, the rapidly growing organism $M$. hassiacum seems to be phylogenetically near the slowly growing organism $M$. xenopi. 
Strain 3849 is the type strain and has been deposited in the Deutsche Sammlung von Mikroorganismen und Zellkulturen GmbH, Braunschweig, Germany, as strain DSM 44199.

\section{REFERENCES}

1. Applied Biosystems GmbH. 1994. PRISM Ready Reaction DyeDeoxy terminator cycle sequencing kit protocol handbook. Applied Biosystems $\mathrm{GmbH}$, Weiterstadt, Germany,

2. Böddinghaus, B., T. Rogall, T. Flohr, H. Blöcker, and E. C. Böttger. 1990. Detection and identification of mycobacteria by amplification of rRNA. J. Clin. Microbiol. 28:1751-1759.

3. Corpe, R. F., E. H. Runyon, and W. Lester. 1963. Status of disease due to unclassified mycobacteria. A statement of the subcommittee of therapy. Am. Rev. Respir. Dis. 87:459-461.

3a. Deutsche Sammlung von Mikroorganismen und Zellkulturen. 1993. Catalogue of strains. Deutsche Sammlung von Mikroorganismen und Zellkulturen, Braunschweig, Germany.

4. Deutsches Zentralkomitee zur Bekämpfung der Tuberkulose. 1991. Die Bakteriologie der Tuberkulose. Pneumologie 45:753-774.

5. DIN. 1991. DIN 58943, parts 3, 8, and 9. Beuth Verlag, Berlin, Germany.

6. du Moulin, G. C., and K. D. Stottmeier. 1986. Waterborne mycobacteria: an increasing threat to health. ASM News 52:525-529.

7. Flourny, D. J. 1993. Non acid-fastness of Mycobacterium fortuitum. Med. Sci. Res. 21:665.

8. Goodfellow, M., and L. G. Wayne. 1982. Taxonomy and nomenclature, p. 472-521. In C. Ratlege and J. L. Stanford (ed.), The biology of the mycobacteria. Academic Press, London, United Kingdom.

9. Graybill, J. R., J. Silva, D. W. Fraser, R. Lordon, and E. Rogers. 1974 Disseminated mycobacteriosis due to Mycobacterium abscessus in two recipients of renal homografts. Am. Rev. Respir. Dis. 109:4-10.

10. Haas, W. H., P. Kirschner, S. Ziesing, H.-J. Bremer, and E. C. Böttger 1993. Cervical lymphadenitis in a child caused by a previously unknown mycobacterium. J. Infect. Dis. 167:237-240.

11. Kent, P. T., and G. P. Kubica. 1985. Public health mycobacteriology: a guide for the level III laboratory. U.S. Department of Health and Human Services publication (CDC) 71-146, p. 71-146. Centers for Disease Control, Atlanta, Ga.

12. Kirschner, P., A. Meier, and E. C. Böttger. 1993. Genotypic identification and detection of mycobacteria-facing novel and uncultured pathogens, $p$. 173-190. In D. H. Pershing, T. F. Smith, F. C. Tenover, and T. J. White (ed.), Diagnostic molecular microbiology: principles and applications. American Society for Microbiology, Washington, D.C.

13. Kroppenstedt, R. M. 1985. Fatty acid and menaquinone analysis of actinomycetes and related organisms. Soc. Appl. Bacteriol. Tech. Ser. 20:173-199.

14. Kroppenstedt, R. M., F. Korn-Wendisch, V. J. Fowler, and E. Stackebrandt. 1981. Biochemical and molecular genetic evidence for transfer of Actinoplanes armeniacus into the family Streptomycetaceae. Zentralbl. Bakteriol. Parasitenkd. Infektionskr. Hyg. Abt. 1 Orig. Reihe C 2:254-262.

15. Kubica, G. P., and L. G. Wayne. 1984. The mycobacteria-a sourcebook, part A, p. 38-164. Marcel Dekker, Inc., New York, N.Y.

16. Kuykendall, L. D., M. A. Roy, J. J. O'Neill, and T. E. Devine. 1988. Fatty acids, antibiotic resistance, and deoxyribonucleic acid homology groups of Bradyrhizobium japonicum. Int. J. Syst. Bacteriol. 38:358-361.

17. Mesbah, M., U. Premachandran, and W. B. Whitman. 1989. Precise measurement of the $\mathrm{G}+\mathrm{C}$ content of deoxyribonucleic acid by high-performance liquid chromatography. Int. J. Syst. Bacteriol. 39:159-167.

18. Miller, L. T. 1982. A single derivatization method for bacterial fatty acid methyl esters including hydroxy acids. J. Clin. Microbiol. 16:584-586.

19. Minnikin, D. E., A. G. O'Donnell, M. Goodfellow, G. Alderson, M. Athalye, A. Schaal, and J. H. Parlett. 1984. An integrated procedure for the extraction of isoprenoid quinones and polar lipids. J. Microbiol. Methods 2:233241

20. Minnikin, D. E., I. G. Hutchinson, A. B. Caldicott, and M. Goodfellow. 1980. Thin-layer chromatography of methanolysates of mycolic acid-containing bacteria. J. Chromatogr. 188:221-233.

21. Naumann, L., and S. Rüsch-Gerdes. Personal communication.

22. Reischl, U., M. Pulz, W. Ehret, and H. Wolf. 1994. PCR-based detection of mycobacteria in sputum samples using a simple and reliable DNA extraction protocol. BioTechniques 17:844-846.

23. Rogall, T., J. Wolters, T. Flohr, and E. C. Böttger. 1990. Towards a phylogeny and definition of species at the molecular level within the genus Mycobacterium. Int. J. Syst. Bacteriol. 40:323-330.

24. Runyon, E. H., A. G. Karlson, G. P. Kubica, and L. G. Wayne. 1980. Mycobacterium, p. 150-179. In E. H. Lennette, A. Balows, W. J. Hausler, Jr., and J. P. Truant (ed.), Manual of clinical microbiology. American Society for Microbiology, Washington, D.C.

25. Sanger, R., A. R. Coulson, G. F. Hong, D. F. Hill, and G. B. Petersen. 1982. Nucleotide sequence of bacteriophage lamda DNA. J. Mol. Biol. 162:729773.

26. Shinnick, T. M., and R. C. Good. 1994. Mycobacterial taxonomy. Eur. J. Clin. Microbiol. Infect. Dis. 13:889-895.

27. Springer, B., P. Kirschner, G. Rost-Meyer, K. H. Schröder, R. M. Kroppenstedt, and E. C. Böttger. 1993. Mycobacterium interjectum, a new species isolated from a patient with chronic lymphadenitis. Int. J. Syst. Bacteriol. 31:3083-3089.

28. Springer, B., L. Stockman, K. Teschner, G. D. Roberts, and E. C. Böttger. 1996. Two-laboratory collaborative study on identification of mycobacteria: molecular versus phenotypic methods. J. Clin. Microbiol. 34:296-303.

29. Stanek, J. L., and G. D. Roberts. 1974. Simplified approach to identification of aerobic actinomycetes by thin-layer chromatography. Appl. Microbiol. 28:226-231.

30. Tamaoka, J., and K. Komagata. 1984. Determination of DNA base composition by reverse-phase high-performance liquid chromatography. FEMS Microbiol. Lett. 25:125-128.

31. Visuvanathan, S., M. T. Moss, J. L. Stanford, J. Hermon-Taylor, and J. J. McFadden. 1989. Simple enzymatic method for isolation of DNA from diverse bacteria. J. Microbiol. Methods 10:59-64.

32. Wolinsky, E. 1979. Nontuberculous mycobacteria and associated diseases. Am. Rev. Respir. Dis. 119:107-159. 